\title{
Evaluation of HBsAg, Anti-HCV, Anti-HIV Seroprevalence and Perinatal Outcomes in Pregnant Women
}

\section{Gebe Kadınlarda HBsAg, Anti-HCV, Anti-HIV Seroprevalansının ve Perinatal Sonuçların Değerlendirilmesi}

\author{
๑ Kazım Uçkan¹, ๑ Izzet Çeleğen², ๑ Taner Uçkan³ \\ ${ }^{1}$ Van Training and Research Hospital, Clinic of Obstetrics and Gynecology, Van, Turkey \\ 2 Van Yüzüncü Yıl University Faculty of Medicine, Department of Public Health, Van, Turkey \\ `Van Yüzüncü Yıl University, Başkale Vocational School, Computer Programming, Van, Turkey
}

\begin{abstract}
Objectives: Vertical transmission of hepatitis B virus, hepatitis $\mathrm{C}$ virus, (HBV, HCV) and human immunodeficiency viruses (HIV) infections is an important public health problem. The aim of this study was to determine the rates of hepatitis B, anti-HCV and antiHIV seropositivities in pregnant women in a city and to evaluate the infections in terms of perinatal outcomes.

Materials and Methods: In this retrospective study, 8,464 patients who gave birth in obstetrics and gynecology clinic were recorded. Seropositivity rates of pregnant women were investigated according to the results of hepatitis B surface antigen (HBsAg), HCV antibody and anti-HIV antibody. The rates were determined according to years and perinatal results and statistical comparison was made. Results: HBsAg seropositivity in pregnant women included in the study was $2.8 \%(n=55)$ in $2015,2.2 \%(n=52)$ in $2016,2.3 \%(n=47)$ in 2017 and $2.2 \%(n=49)$ in 2018 . The 4 year average was found to be $2.3 \%(n=203)$. There was no significant difference between the years $(p>0.05)$. Among all our patients, 4-year mean anti-HCV seropositivity was $0.57 \%(n=49)$ and there was no difference between years $(p>0.05)$. Anti-HIV seropositivity was found to be $0.09 \%$ on average, and there was no statistically significant difference over the years ( $p>0.05)$.

Conclusion: Since hepatitis B, which is a preventable viral disease, has a risk of transmission during delivery and if it is transmitted to the fetus, it may lead to fatal complications at later ages, it is necessary to screen all pregnant women in terms of HBsAg seropositivity and to include it in an antepartum planning program to protect and treat newborns from infection. Although the transmission rate of HCV is low in the society, considering its clinical course, screening of HCV
\end{abstract}

$0 ̈ Z$

Amaç: Hepatit B virüsü, hepatitis C virüsü (HBV, HCV) ve insan immün yetmezlik virüsleri (HIV) enfeksiyonlarının dikey bulaşması önemli bir halk sağlığı problemidir. Bu çalışmadaki amaç bir ildeki gebelerde hepatit $\mathrm{B}$, anti-HCV ve anti-HIV seropozitiflik oranlarını belirlemek ve enfeksiyonları perinatal sonuçlar açısından değerlendirmektir. Gereç ve Yöntemler: Bu retrospektif çalışmada kadın hastalıkları ve doğum kliniğinde doğumu gerçekleştirilmiş 8,464 hasta kayıt altına alınmıştır. Gebelerde seropozitiflik oranları, hepatit B yüzey antijeni (HBsAg), HCV antikoru ve tespit edilen anti-HIV antikoru sonuçlarına göre araştırıldı. Yıllara göre ve perinatal sonuçlara göre oranlar belirlenip istatistiki karşılaştırma yapıldı.

Bulgular: Çalışmaya alınan gebelerde HBsAg seropozitifliği 2015 yllında \%2,8 ( $n=55), 2016$ yilında \%2,2 ( $n=52), 2017$ yllında \%2,3 $(n=47)$ ve 2018 yllında ise $\% 2,2 \quad(n=49)$ bulunmuş olup 4 yillık ortalaması \%2,3 ( $n=203)$ olarak hesaplanmıştır. Yıllar arasında anlamlı bir farklılık gözlenmemiştir ( $p>0,05)$. Tüm hastalarımı içinde dört ylllık ortalama anti-HCV seropozitifliği \%0,57 ( $n=49)$ olup yıllar arasında fark bulunmadı $(p>0,05)$. Anti-HIV seropozitifliği ortalama olarak \%0,09 olarak saptanmış olup yıllara göre istatistiki anlamda bir farkllık izlenmemiştir ( $p>0,05)$.

Sonuç: Önlenebilir bir viral hastalık olan hepatit B'nin doğum esnasında bulaş riski olduğundan ve fetusta bulaş olursa ilerleyen yaşlarda ölümcül komplikasyonlara yol açabileceğinden tüm gebelerin HBsAg seropozitifliği açısından taranması ve bunun bir antepartum planlama programına dahil edilmesi yenidoğanların enfeksiyondan korunması ve tedavi edilmesi için gereklidir. HCV'nin toplumda bulaş oranı düşük bir düzeyde olmasına karşın klinik

Uçkan K, Çeleğen I, Uçkan T. Evaluation of HBsAg, Anti-HCV, Anti-HIV Seroprevalence and Perinatal Outcomes in Pregnant Women. Viral Hepat J. 2021;27:103-108.

Address for Correspondence: Kazım Uçkan MD, Van Training and Research Hospital, Clinic of Obstetrics and Gynecology, Van, Turkey

E-mail: druckan65@hotmail.com ORCID ID: orcid.org/0000-0002-5576-6789 Received: 06.12.2020 Accepted: 20.06.2021

${ }^{\circ}$ Copyright 2021 by Viral Hepatitis Society / Viral Hepatitis Journal published by Galenos Publishing House. 


\section{ABSTRACT}

together with HIV in risky groups and pregnant women antibody positivity is considered important for the health of the society and newborns.

Keywords: Seroprevalance, pregnancy, HBsAg, anti-HCV, anti-HIV, perinatal outcomes
$\ddot{O Z}$

seyri dikkate alındığında riskli gruplarda ve gebelerde HIV ile birlikte taranması toplum ve yenidoğan bebeklerin sağlığı için önemli görülmektedir.

Anahtar Kelimeler: Seroprevalans, gebelik, HBsAg, anti-HCV, antiHIV, perinatal sonuçlar

\section{Introduction}

Hepatitis B virus (HBV) and hepatitis C virus (HCV) infections seen worldwide are still important infectious diseases today. Hepatitis is the most common infection in our country and HBV, which is the leading one, is a major health problem $(1,2)$. Although there are many ways of transmission of hepatitis $B$, it is a viral agent that can be transmitted most frequently with infected body fluids, through permucosal or percutaneous contact. Viral encounter can occur between individuals living in the same house through sexual or parenteral transmission, with vertical transition from mother to baby, and horizontal transmission (3). Since almost half of the carriers receive HBV in the perinatal period, transmission from mother to baby draws attention as an important way of transmission of this virus (4). Perinatal transmission is rarely seen after birth, and it is known that $5-10 \%$ is transplacentally. Transition from mother to baby usually occurs during birth and $70-90 \%$ of these babies can be chronic carriers (5). In our country, which is in a moderately endemic region and has an hepatitis $B$ surface antigen (HBsAg) seroprevalence rate of 3.9-12.5\%, regional differences can be observed (6).

It is known that millions of people around the world have HCV infection. It has been reported that the risk of transmission to the baby is less than $5 \%$ in mothers who are positive after the HCVRNA test. There is no special protection method to prevent perinatal transmission of HCV. However, pregnant women with a high viral load can infect newborns and the infection can become chronic in babies who develop acute infection (7). The number of anti-human immunodeficiency virus (anti-HIV) positive cases reported each year in Turkey is increasing. It is seen that approximately $0.8 \%$ of HIV cases are transmitted from infected mother to baby (8). Although the benefits of the measures to prevent the perinatal transmission of HCV have not been fully determined today (9), it is recommended to screen patients who come for pregnancy followup, as the measures to be taken during pregnancy may reduce the risk of transmission for hepatitis B and HIV (10). HCV antibodies (anti-HCV) for HCV, HBsAg for HBV, HIV antibodies (anti-HIV) for HIV are markers screened in the blood.

It is important to know the presence of viruses in early interventions in babies with a healthy follow-up of pregnant women and in deliveries with seropositivity. The aim of this study is to determine the rates of hepatitis $\mathrm{B}$, anti-HCV and anti HIV seropositivity in pregnant women in a province and to evaluate the infections in terms of perinatal outcomes.

\section{Materials and Methods}

Eight thousand four hundred and sixty four pregnant women who were delivered in the Gynecology and Obstetrics Clinic of
Van Training and Research Hospital between January 1, 2015 and December 31, 2018 were included in the study. HBsAg, antiHCV and anti-HIV seropositivity rates were examined by ELISA method in pregnant women. Age, abortion, parity, gravida number, birth weight, gestational age, and demographic characteristics were recorded retrospectively by archive registry scanning. In the study, patients who were anti-HIV positive in ELISA results were detected during delivery. With the recommendation of this group of patients to the prenatal infectious diseases clinic, HIV-RNA tests were taken immediately, antiretroviral treatment was initiated, and their deliveries were carried out by cesarean section. Postnatal antiretroviral treatment and follow-up were carried out by the infectious diseases clinic.

Patients with positive HBsAg values were detected during delivery. Emergency deliveries of this patient group were realized and HBV-DNA, HBeAg positivity, treatment, and follow-up were carried out by the infectious diseases clinic in the postpartum period.

Ethics committee approval was obtained for the study from Van Ministry of Health University Training and Research Hospital Clinical Research and Ethics Committee with the decision number of 2019/05 and dated 07-03-2019. Written informed consent was obtained from the patients included in the study and our study was conducted in accordance with the Declaration of Helsinki Principles.

\section{Statistical Analysis}

Data were analyzed using (SPSS) 20.0. Student's t-test was used for comparing the means between independent groups, and the chi-square test was used to compare categorical variables. Descriptive statistical methods (number, mean, standard deviation) were used. $\mathrm{P}<0.05$ was considered significant.

\section{Results}

Eight thousand four hundred and sixty four pregnant women between the specified dates were included in the study. Mean delivery week of the pregnant women participating in the study is $38.5 \pm 3.3$ weeks. The average birth weight of babies is $3,156.6 \pm 547.8$ grams. HBsAg seropositivity in pregnant women included in the study was found to be $2.8 \%(n=55)$ in $2015,2.2 \%$ $(n=52)$ in 2016, 2.3\% $(n=47)$ in 2017 and 2.2\% ( $n=49)$ in 2018 and the 4-year average was found to be $2.3 \%(n=203)$. There was no statistically significant difference between the years in terms of HBsAg positivity ( $p>0.96$ ). Anti-HCV seropositivity in pregnant women included in the study was found to be $0.4 \%(n=9)$ in 2015 , $0.5 \%(n=13)$ in 2016, 0.5\% $(n=12)$ in 2017 and $0.6 \%(n=15)$ in 2018. The 4 -year average was found to be $0.57 \%(n=49)$. There 
was no statistically significant difference between the years in terms of anti HCV positivity ( $p>0.63$ ). Anti-HIV seropositivity in pregnant women included in the study was found to be $0.05 \%$ $(n=1)$ in 2015, 0.08\% $(n=2)$ in 2016, 0.14\% $(n=3)$ in 2017 and $0.09 \%(n=2)$ in 2018 , the average was found to be $0.09 \%(n=8)$. There was no statistically significant difference between the years in terms of anti HIV seroprevalence ( $p>0.74)$. The distribution of HBsAg, anti-HCV and anti-HIV values and the number of births by years is shown in Table 1 and Figure 1.

According to age groups, HBsAg $(n=8,464)$ seroprevalence was determined as $2.5 \%, 2.4 \%, 2.4 \%$ and $2.3 \%$, respectively. Anti-HCV seroprevalence $(n=8,464)$ was determined as $0.4 \%$, $0.6 \%, 0.5 \%$, and $0.5 \%$, respectively, according to age groups.

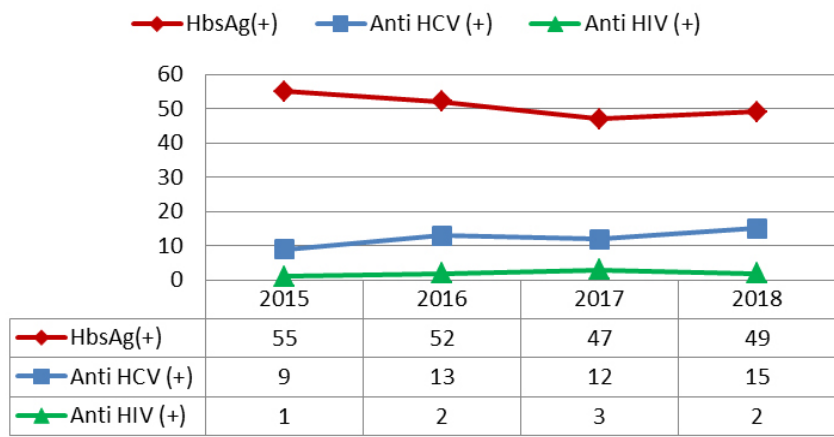

Figure 1. Distribution of HBsAg (+), anti-HCV (+), anti-HIV (+) births by years

HBsAg: Hepatitis B surface antigen, HCV: Hepatitis C virus, HIV: Human immunodeficiency virus
Anti-HIV seroprevalence was found to be $0.07 \%, 0.07 \%, 0.07 \%$ and $0.15 \%$, respectively, according to age groups. There was no statistically significant difference between age groups and $\mathrm{HBsAg}$ anti-HCV and anti-HIV positive/negativity $(p>0.43, p>23, p>0.26$ respectively) (Table 2).

There was no statistically significant difference between $\mathrm{HBsAg}$, anti-HCV, anti-HIV positivity/negativity according to some perinatal variables (abortion, parity, gravida, gestational week and birth weight) ( $p>0.05$ ) (Table 3).

\section{Discussion}

When looking at the distribution of HBV infection in the world, where Turkey is in the middle endemisite group, there are three endemic regions: low, medium and high (6). Hepatitis B vaccination was put into the vaccination program by many countries and there was a significant reduction in the disease there. However, in countries without hepatitis B vaccination program, the disease is still seen at high rates. In our country, as in most countries, the frequency of hepatitis B has decreased significantly over the years after the vaccination program was implemented (11). Horizontal and perinatal infection have been reported as the most important infectious pathways of hepatitis B infection. With the addition of low socioeconomic environment and poor hygiene conditions to crowded and public environments such as domestic, nursery, school, prisons, boarding school and kindergarten, the rate of infection increases even more (12).

Chronic HBV infection due to mother-to-child transmission in the perinatal period continues to be an important global health problem. Despite the standard passive-active immunoprophylaxis

\begin{tabular}{|c|c|c|c|c|c|c|c|c|c|c|}
\hline Year & HBsAg (+) n (\%) & HBsAg (-) n (\%) & p & $\begin{array}{l}\text { Anti-HCV (+) } \\
\text { n (\%) }\end{array}$ & $\begin{array}{l}\text { Anti-HCV (-) } \\
\text { n (\%) }\end{array}$ & $p$ & $\begin{array}{l}\text { Anti-HIV (+) } \\
\text { n (\%) }\end{array}$ & $\begin{array}{l}\text { Anti-HIV (-) } \\
\mathrm{n}(\%)\end{array}$ & p & Total \\
\hline 2016 & $52(2.2)$ & 2308 (97.8) & \multirow{4}{*}{0.96} & $13(0.5)$ & 2347 (99.5) & \multirow{4}{*}{0.63} & $2(0.08)$ & $2358(99.92)$ & \multirow{4}{*}{0.74} & 2360 \\
\hline 2017 & $47(2.3)$ & 1983 (97.7) & & $1(0.5)$ & 2018 (99.5) & & $3(0.1)$ & 2027 (99.9) & & 2030 \\
\hline 2018 & $49(2.2)$ & 2106 (97.8) & & $1(0.6)$ & $2140(99.4)$ & & $2(0.09)$ & 2153 (99.91) & & 2155 \\
\hline Total & $203(2.3)$ & 8261 (97.3) & & $4(0.5)$ & 8415 (99.5) & & $8(0.09)$ & 8456 (99.91) & & 8464 \\
\hline
\end{tabular}

\begin{tabular}{|c|c|c|c|c|c|c|c|c|c|c|}
\hline Age & $\begin{array}{l}\text { HBsAg (+) } \\
n(\%)\end{array}$ & $\begin{array}{l}\text { HBsAg (-) } \\
\text { n (\%) }\end{array}$ & $\mathrm{p}$ & $\begin{array}{l}\text { Anti-HCV (+) } \\
\text { n (\%) }\end{array}$ & $\begin{array}{l}\text { Anti-HCV (-) n } \\
(\%)\end{array}$ & $p$ & $\begin{array}{l}\text { Anti-HIV (+) } \\
\mathrm{n}(\%)\end{array}$ & $\begin{array}{l}\text { Anti-HIV (-) } \\
\mathrm{n}(\%)\end{array}$ & $p$ & Total \\
\hline$>20$ & $65(1.4)$ & $4,331(98.6)$ & 0.43 & $25(0.6)$ & $4,412(99.4)$ & 0.23 & $5(0.1)$ & 4,432 (99.9) & 0.56 & 4,437 \\
\hline
\end{tabular}


Table 3. HBsAg, anti-HCV and anti-HIV distribution according to abortion, parity, gravida, gestational week and birth weight

\begin{tabular}{|c|c|c|c|c|c|c|c|c|c|}
\hline & $\begin{array}{l}\text { HBsAg }(+) \\
(\text { mean } \pm \text { SD) }\end{array}$ & $\begin{array}{l}\text { HBsAg }(-) \\
(\text { mean } \pm \text { SD) }\end{array}$ & $p$ & $\begin{array}{l}\text { Anti-HCV (+) } \\
(\text { mean } \pm \text { SD) }\end{array}$ & $\begin{array}{l}\text { Anti-HCV (-) } \\
\text { (mean } \pm \text { SD) }\end{array}$ & p & $\begin{array}{l}\text { Anti-HIV (+) } \\
(\text { mean } \pm \text { SD) }\end{array}$ & $\begin{array}{l}\text { Anti-HIV (-) } \\
\text { (mean } \pm \text { SD) }\end{array}$ & p \\
\hline Abortion (n) & $1.2 \pm 0.3$ & $0.9 \pm 0.2$ & 0.67 & $1.1 \pm 0.4$ & $0.9 \pm 0.5$ & 0.54 & $0.8 \pm 0.2$ & $0.7 \pm 0.1$ & 0.43 \\
\hline Parity (n) & $2.0 \pm 0.2$ & $1.9 \pm 0.7$ & 0.45 & $2.3 \pm 0.6$ & $1.7 \pm 0.3$ & 0.34 & $2.2 \pm 0.5$ & $2.0 \pm 0.5$ & 0.37 \\
\hline Gravida (n) & $2.5 \pm 1.4$ & $2.3 \pm 1.1$ & 0.43 & $2.8 \pm 0.5$ & $2.6 \pm 1.4$ & 0.38 & $3.3 \pm 1.1$ & $2.8 \pm 0.7$ & 0.21 \\
\hline Gestational week & $39.3 \pm 2.5$ & $38.4 \pm 3.6$ & 0.21 & $38.6 \pm 3.1$ & $38.4 \pm 2.6$ & 0.17 & $38.4 \pm 3.6$ & $37.6 \pm 2.3$ & 0.52 \\
\hline Birth weight (gr) & $3292.2 \pm 337$ & $3284.3 \pm 643$ & 0.12 & $3333.5 \pm 323$ & $3300.5 \pm 232$ & 0.26 & $3233.4 \pm 323$ & $3404.4 \pm 245$ & 0.15 \\
\hline
\end{tabular}

with hepatitis B immunoglobulin ( $\mathrm{HBIG}$ ) and hepatitis B vaccine in newborns, up to $9 \%$ of newborns are still infected with HBV. Chronic HBV infection due to transmission from mother to child in the perinatal period is an important global health problem. Standard passive-active immunoprophylaxis with $\mathrm{HBIG}$ and HBV vaccine in newborns within 12 hours after birth has proven successful in protecting approximately $90 \%$ of newborns from perinatal transmission of HBV (13).

Considering the studies conducted on pregnant women around the world, the prevalence of chronic hepatitis B was found to be $5 \%$ on average. Depending on the endemic situation in the region, it can be seen at different rates from $0.6 \%$ to high rates exceeding $20 \%(14,15)$.

HBsAg rate in pregnant women in studies on hepatitis B prevalence in pregnant women in Turkey was determined to be $4.7 \%$. It was stated that pregnant women should be screened for $\mathrm{HBV}$ in order to protect newborns from hepatitis B infection (16). In another study covering the period 2001-2009, they found the hepatitis B carrier rate in pregnant women to be $2.5 \%$ (17). In a comprehensive study involving 90351 pregnant women, it was stated as $2.1 \%$ HBsAg positivity and it was recommended that hepatitis $\mathrm{B}$ examination be performed for every pregnant who comes to follow up (18). In a nationwide study conducted on 20,472 people between 1987-1998, HBsAg and anti-HBs positivity were reported as $4.4 \%$ and $23 \%$, respectively. In another nationwide study conducted between 1998 and 2012, 4.3\% of the 41,107 people tested were HBsAg-positive (19). In the study conducted with 9,420 pregnant women, HBsAg was found positive in $4.7 \%$, anti-HBs in $38.4 \%$, and anti-HCV in $0.286 \%$ of pregnant women (20). In a 20-year evaluation study; 7,605 pregnant women were tested, HBsAg prevalence was $1.5 \%$ and anti-HBs positivity was $11.5 \%$, respectively (21). In the study in which 35,295 pregnant women were tested; HBsAg and anti-HBs levels were positive in 425 (1.2\%) and 9,583 (27.7\%) patients, respectively. In this study, it is stated that from 2013 to 2016, HBV carrier rates decreased from $1.4 \%$ to $0.8 \%$, while anti-HBs positivity increased from $25.4 \%$ to $30.2 \%(22)$.

In our study, HBsAg positivity rates were $2.8 \%$ in $2015,2.2 \%$ in $2016,2.3 \%$ in 2017 , and $2.2 \%$ in 2018 . The four year average positivity rate is $2.3 \%$, which is consistent with the literature and supports the fact that we are in the middle endemicity region. Although there are regional differences in these studies, it is seen that the rate of carrier has decreased over the years. The low rate in our study may be related to the increase in social awareness with the spread of hepatitis B vaccine and its inclusion in the routine vaccination program. In addition, the catch-up vaccination initiated after the hepatitis B vaccine was included in the national vaccination program may have also contributed to the decrease in these rates.

Hepatitis B vaccines, which are typically used in three doses, have been included in the routine vaccination program in Turkey since August 1998. While it is administered in 3 (three) doses in the normal administration scheme, vaccination is recommended at $0,1,2$, and 12. months for people with infection risk. Considering the risk of perinatal transmission, HBIG should be administered in addition to hepatitis $B$ vaccine in the first 24 hours in the postpartum period to newborns from HBV-infected mothers (23).

All babies born from HBsAg positive mothers born in our clinic were consulted by pediatricians. These babies were given HBIG in addition to hepatitis $B$ vaccine. In addition, infected mothers were followed up by infectious diseases physicians.

Since there is no vaccine and antiviral treatment that can reduce the vertical transmission of the infection in pregnant women with anti-HCV positivity, the necessity of routine testing during pregnancy is discussed. However, it has been reported that conditions such as cesarean section and not breastfeeding in elective conditions do not reduce the vertical transmission of $\mathrm{HCV}$ infection (9). Considering the studies conducted abroad on anti HCV seropositivity, the seroprevalence in Burkino Faso was determined to be $5.4 \%$ and it was stated that this viral agent was mostly transmitted by sexual intercourse (24). In the study conducted on pregnant women in Switzerland, a rate of $0.71 \%$ was found (25). There are many studies on anti-HCV positivity in pregnant women in our country. Anti-HCV positivity was detected as $0.6 \%$ in the study of Gönen (26) In the study covering 20062012, the anti-HCV rate in pregnant women was found to be $0.5 \%$ (27). The anti-HCV positivity rate in Turkey has been reported to be in the range of $0-1.5 \%$ in the general population and $0-2.04 \%$ in pregnant women (28).

In our study, anti-HCV rates in all pregnant women were $0.4 \%$ in $2015,0.5 \%$ in $2016,0.5 \%$ in 2017 and $0.6 \%$ in 2018. The average four year anti-HCV rate is $0.5 \%$. There was no difference between the years and it is compatible with the literature.

Prevention of HIV transmission from mother to newborn is possible by screening the mother during pregnancy, antiviral treatment and prophylaxis applied to the newborn after birth. Especially pregnant women in the risk group should be screened in HIV-endemic regions (29). Since there is a high risk of transmission 
to the baby during delivery in infected mothers with HIV positivity, early diagnosis of HIV and rapid initiation of treatment is of great importance as it may prevent transmission to the baby. It is important to take measures such as starting antiretroviral therapy immediately after diagnosis, planning the delivery method by cesarean section and not breastfeeding the baby in the postpartum period (30) Özlü et al. (27) could not detect a positivity in their study. Madendağ et al. (18) detected a positivity of $0.004 \%$ in their study. In a recent study, all 7,113 pregnant women screened for HIV had negative results (22).

Although there are not enough studies on the subject in our country, it is observed that anti-HIV positivity is low in studies. In the study, the average of four-year anti-HIV positivity was $0.09 \%$, and the rate ranged from $0.05 \%$ to $0.14 \%$ according to years. The positivity rates are similar to the low case rates detected in our country.

In our study, no significant difference was found between age groups in terms of HBsAg, anti-HCV and anti-HIV seropositivity. This finding indicates that all age groups may be at similar risk for these infections. Similarly, in a study performed on 5,894 patients, no significant difference was found between age groups in terms of HBsAg and anti-HCV seropositivity (31). In the literature, it is stated that the anti-HCV positive patient group is mostly in the advanced age groups $(32,33)$ We think that the reason for the lack of difference between age groups in our study is that the pregnant women in reproductive age who gave birth were in a certain age range.

Considering the studies conducted on HBsAg, anti-HCV and anti-HIV seropositivity in our country, it is seen that studies on the relationship between these infections and pregnancy conditions such as gravida, parity, abortion, birth weight and gestational week are not sufficient. Since all pregnant women in our study were followed-up in our outpatient clinics and their deliveries were carried out in the maternity ward of our clinic, the data were reached safely. In our study, no statistically significant difference was observed between HBsAg, anti-HCV and anti-HIV positivity rates and important perinatal outcomes such as abortion, gravida, parity number, birth weight and gestational week among all pregnant women. In a study conducted in our country, it was reported that there was no significant difference between the $\mathrm{HBsAg}$ and anti-HCV groups in terms of abortion, gravida, parity and the number of living children (34).

\section{Study Limitation}

The results of the research are valid only for the group in which the research was conducted cannot be generalized.

\section{Conclusion}

We think that all pregnant women should be screened for HBsAg, anti-HCV and anti-HIV serology during pregnancy follow-up. Babies born from HBsAg positive mothers should receive HBIG in addition to the postnatal vaccine. Although the transmission risk of $\mathrm{HCV}$ is low, we recommend screening pregnant groups in terms of the health status of the society and newborns. In addition, in case of detection of anti HIV positivity, anti HIV testing may be recommended, especially in risky groups, since it is an antiretroviral treatment option. In addition, we think that it would be appropriate to examine HBsAg, anti-HCV and anti-HIV tests at the first examination in pregnant women with low socio-economic status and coming from rural areas. In addition to all these, we believe that it would be beneficial to know the HBsAg, anti-HCV and antiHIV serologies of the patients in order to protect obstetricians and gynecologists from these viruses.

\section{Ethics}

Ethics Committee Approval: Ethics committee approval was obtained for the study from Van Ministry of Health University Training and Research Hospital Clinical Research and Ethics Committee with the decision number of 2019/05 and dated 07-032019.

Informed Consent: Written informed consent was obtained from the patients included in the study and our study was conducted in accordance with the Declaration of Helsinki Principles.

Peer-review: Externally peer-reviewed.

\section{Authorship Contributions}

Surgical and Medical Practices: K.U., I.Ç., T.U., Concept: K.U., I.Ç., T.U., Design: K.U., I.Ç., T.U., Data Collection or Processing: K.U., I.Ç., T.U., Analysis or Interpretation: K.U., I.Ç., T.U., Literature Search: K.U., I.Ç., T.U., Writing: K.U., I.Ç., T.U.,

Conflict of Interest: Regarding this study, the authors and/or their family members do not have a scientific and medical committee membership or relationship with their members, consultancy, expertise, working status in any company, shareholding or similar situations that may have a potential conflict of interest.

Financial Disclosure: During this study, no support was received from any pharmaceutical company that has a direct connection with the research subject, or a company that provides and/or produces medical tools, equipment and supplies. In addition, no financial and/or moral support was received from any commercial firm during the evaluation process of the study that could affect the decision about the study negatively.

\section{References}

1. Curry MP, Chopra S. Acute viral hepatitis. Principles and practice of infectious diseases. Philadelphia: Elsevier Churchill Livingstone; 2005; pp. 1426-1441.

2. Aygen B. Hepatit A Virusu. Ed: Willke Topçu A, Söyletir G, Doğanay M. Infectious Diseases and Microbiology Volume II. Istanbul; Nobel Medical Bookstores, 2002; pp. 1340-9.

3. Aspinall EJ, Hawkins G, Fraser A, Hutchinson SJ, Goldberg D. Hepatitis B prevention, diagnosis, treatment and care: a review. Occupational Med 2011;61:531-540.

4. Mıstık R, Balık I. Epidemiological analysis of viral hepatitis in Turkey. Viral Hepat J 2003;1:10-55.

5. Ghendon Y. Perinatal transmission of hepatitis B virus in highincidence countries. J Virol Methods 1987;17:69-79.

6. Taşyaran MA. Epidemiology of HBV Infection. Tekeli E, Balık I, editors. 1st Edition. Istanbul: Character Color A.Ş; 2003; pp. 121128.

7. Wasmuth JC. Hepatitis B-Epidemiology, transmission and natural history. In: Mauss S, Berg T, Rockstroh J, SarrazinC, Wedemeyer H, editors. Hepatology. Dusseldorf: Flying Publisher; 2009; pp. 37-48.

8. Turhan NÖ, Kaygusuz IÇ, Pekel A. Assisted Reproduction Techniques in HIV Positive Couples: Review. Turkiye Klinikleri J Gynecol Obst 2007;117-125. 
9. Arshad M, El-Kamary SS, Jhaveri R. Hepatitis C virus infection during pregnancy and the newborn period-are they opportunities for treatment? Viral Hepat J. 2011;18:229-236

10. LeFevre ML. U.S. Preventive Services Task Force. Screening for hepatitis B virus infection in nonpregnant adolescents and adults: U.S. Preventive Services Task Force recommendation statement. Ann Intern Med 2014;161:58-66.

11. Tosun S. The changing epidemiology of viral hepatitis in our country. Ankem J 2013;27:128-134.

12. Kartal B. Knowledge Levels and Practices on Hepatitis B of Mothers of 0-6 Age Group Children Admitted to Nevsehir State Hospital Pediatrics Service, (Master Thesis), Erciyes University Institute of Health Sciences, Kayseri; 2003.

13. Yi P, Chen R, Huang Y, Zhou RR, Fan XG. Management of motherto-child transmission of hepatitis $B$ virus: propositions and challenges. J Clin Virol 2016;77:32-39.

14. Petrova M, Kamburov V. Breastfeeding and chronic HBV infection: clinical and social implications. World J Gastroenterol 2010;16:5042

15. Petersen J. HBV treatment and pregnancy. J Hepatol 2011;55:117.

16. Kölgelier S, Güler D, Demiraslan H. HBsAg and Anti-HCV prevalence in pregnant women in Adıyaman. Dicle Med $\mathrm{J}$ 2009;36:191-194

17. Polat $S$, Camurdan AD, Aksakal N, Agladioglu S, Beyazova, U, Sahin F, Er A. Evaluation of perinatal and intrafamilial hepatitis B prevention programmes in a well child clinic: 9-year follow-up study in Turkey. Trans R Soc Trop Med Hyg 2011;105:220-225.

18. Madendağ $Y$, Çöl Madendağ $D$, Çelen Ş, Ünlü S, Danşman N. All obstetric and gynecological patients in our hospital applicant Hepatitis B, Hepatitis C and HIV Seroprevalence. Turkey Clin J Gynecol 2007;17: 442-446.

19. Tosun S. Meta-analysis of publications epidemiology of viral hepatitis B in Turkey. In: Tabak F, Tosun S, editors. Viral Hepatitis 2013. 1st Edition Istanbul: Medikal Sağlık ve Yayınclık; 2013; pp. 25-80.

20. Kölgelier S, Demir LS, Demir NA, Özçimen S, Tabak S. Seropositivity of HBsAg and anti-HCV in Pregnant Women in Adiyaman. Viral Hepat J 2012 18:98-101.

21. Furuncuoglu $Y$, Bolukbas FF, Bolukbas C, Torun P. Changes in the prevalence of HBV infection in pregnant women in Turkey between 1995 and 2015: a 20-year evaluation. Postgrad Med J 2016;92:510-513.

22. Tanrıverdi EÇ, Özkurt Z, Kadıoğlu BG, Alay H, Çalıkoğlu O, Koca O, Kamalak Z. Seroprevalence of hepatitis B, hepatitis C, and HIV in pregnant women from Eastern Turkey. Turk $\mathrm{J}$ Gastroenterol 2019:30:260-265.

23. Bilgiç A, Özaçar T. Hepatitis B Virus Infection Diseases and Microbiology. Istanbul, Nobel Medical Bookstores; 2002; pp. 1350-1370.

24. Collenberg E, Ouedraogo T, Ganamé J, Fickenscher H, KynastWolf G, Becher H, Tebit D. Seroprevalence of six different viruses among pregnant women and blood donors in rural and urban Burkina Faso: a comparative analysis. J Med Virol 2006;78:683692.

25. Prasad LR, Spicher VM, Kammerlander R. Hepatitis C in a sample of pregnant women in Switzerland: seroprevalence and sociodemografic factors. Swiss Med Wkly 2007;137:27-32.

26. Gönen I. HBV and HCV prevalence in pregnant women in rural areas. J Viral Hepat 2011;17:66-68.

27. Özlü T, Taş T, Mengeloğlu FZ, Koçoğlu E, Dönmez ME. The prevalence of HBsAg, anti-HCV and anti-HIV in pregnant women and / or women with gynecological disease in a tertiary hospital. J Clin Exp Invest 2013;4.

28. Mistık R. The epidemiology of hepatitis $C$ virus infection. In: Tabak F, Tosun S, editors. Viral Hepatitis, 1st Edition Istanbul: Medical Health and Publishing; 2013; pp. 83-112.

29. Rimawi $\mathrm{BH}$, Haddad L, Badell ML, Chakraborty R. Management of HIV infection during pregnancy in the United States: updated evidence-based recommendations and future potential practices. Infect Dis Obstet Gynecol 2016; 2016:7594306

30. Jamieson DJ, Read JS, Kourtis AP, Durant TM, Lampe MA, Dominguez KL. Cesarean delivery for HIV-infected women: recommendations and controversies. Am J Obstet Gynecol 2007;(Suppl3)197:S96-100

31. Balık G, Üstüner I, Kağıtcı M, Ural ÜM, Tekin YB, Şentürk Ş, Şahin FK. HBsAg, AntiHBs and Anti-HCV seroprevalence in pregnant women living in the Rize region. Dicle Med J 2013;40:254-257.

32. Inci A, Okay M, Güven D. HBsAg, Anti-HBs, Anti-HCV and AntiHIV seroprevalence in patients admitted to Artvin state hospital. Viral Hepat J2014;19:41-44.

33. Asan A, Akbulut A, Saçar S, Turgut H. Evaluation of HBsAg and Anti-HCV seroprevalence in people applying to Tunceli State Hospital. J Viral Hepat 2011;17:52-56.

34. Yıldız B, Bucaktepe PGE, Yıldız I, Kara IH. Relationships between HBsAg and AntiHCV Seropositivity Rates and Risk Factors of Pregnant Women Hospitalized in Gynecology and Obstetrics Clinic and Other Patients. Konuralp Med J 4:27-34. 